\title{
DISPOSABLE WORKFORCE IN ITALY
}

\author{
by \\ Bruno Contini and Elisa Grand \\ University of Torino and LABORatorio R. Revelli, Collegio Carlo Alberto
}

(November 2009)

\begin{abstract}
This paper explores the "disposable" patterns of workforce utilization in Italy, well under way before the cyclical downturn of the early 90's and before the main reforms of the Italian labor market. The term "disposable" reflects the fact that many young people enter the labor market, their services are "used" as a disposable commodity for a few years, after which they leave the labor market altogether and are no longer observable in the official (administrative) data. Workforce disposal is evident and dramatic: out of 100 new young entries, about 70 are still in the labor market 10 years after entry if their first job spell was at least one year long. For those - three times as many - who have started their career with a short employment spell ( $<3$ months), 10-year survival does not reach $50 \%$. We show that the order of magnitude of workforce disposal is consistent with the official LFS youth unemployment rate increased by a reasonable estimate of the number of workers who end up in irregular, undetectable activities.
\end{abstract}

Keywords: Youth employment, unemployment, unemployment duration.

JEL Codes: J, J0, J1, J6. 


\section{Introduction}

This paper explores the "disposable" patterns of male workforce utilization in Italy, apparently under way before the cyclical downturn of the early 90's and before the main reforms of the Italian labor market. The term "disposable" reflects the fact that many young people enter the labor market, their services are "used" as a disposable commodity for a few years, after which they are - as it were disposed. "Disposed" in the sense that they are no longer observed in administrative databases that cover the entire population of workers over their lifetime. ${ }^{1}$ In addition to its obvious socio-economic implications - the very low participation rate of young people - workforce disposal has adverse effects on human capital accumulation as the planning horizon becomes too short: skill depletion is one aspect, but the lack of incentives to invest in human capital both for employers and employees is the other, perhaps more important aspect.

To my knowledge, the concept of "disposable workforce" is new. There are, of course, innumerable studies that touch upon more or less closely related issues: unemployment duration and state dependence, labor force outflows at young age, permanent displacement after layoff, labor market segmentation, attrition in longitudinal datasets. A survey of this literature would require a contribution of its own to the JEL, and even the selection of the main contributions for each of the above items would be arbitrary.

In this paper I consider the average pseudo-survival ${ }^{2}$ of cells defined by annual cohorts of young male employees, year of first employment, length of job spells, geographical area, industry and firm size of initial position. A detailed descriptive analysis is provided in the first part of the paper: the "disposable" pattern per se is an important and worrisome discovery. The second part of the paper aims at suggesting a line of interpretation of the short-medium run developments. A more comprehensive exploration of the long run evolution of this aspect of the Italian labor market is, for the time being, problematic for lack of appropriate data.

\footnotetext{
${ }^{1}$ Attrition is the term normally used to define such occurrences in survey-based longitudinal databases. It reflects problems of data collection and management. Here the attrition that we observe is the product of perfectly explainable patterns of workforce utilization, which have nothing to do with data collection. I will no longer refer to attrition in this paper, although some genuine, undistinguishable, attrition may be present in the data. Undoubtedly, however, the latter is a minuscule share of the former.

${ }^{2}$ I use the term "pseudo-survival" to define the process by which workers are disposed. The term "survival" would be inappropriate as a survival function has a well defined meaning in statistics. A pseudo-survival schedule, as defined here, is a time-decreasing function that indicates the number of workers of a given cohort/cell still active in the labor market, i.e. who have not been "disposed" after a given number of years. I will, nonetheless, often use the term "survival" in lieu of "pseudo-survival".
} 
All the data come from the WHIP database, the source of which is the Italian Social Security Administration (INPS).

The key finding of this paper can be summarized as follows: out of 100 new young male entries, between 45 and $85 \%$ are still at work 2 years after entry, 35 to $70 \%$ after 10 years, and only 25 to $40 \%$ after 17 years. A bad start makes a large difference in future outcomes. For those who have had a continuous 12-month employment spell at entry, survival at work after 10 years is about $85 \%$. For those - three times as many - who have started their career with one or more short employment spells ( $<3$ months), survival does not reach 50\%. Among the selfemployed survival is higher ${ }^{3}$. Initial wages are also good predictors of survival: the probability of surviving after a bad start (first job spell $<3$ months and wage $<$ first quartile of the distribution) is about four times as low as that following a good start. ${ }^{4}$

These numbers raise several questions, in addition to the obvious preoccupation for the magnitude of the "disposal" pattern as such, and the adverse effects that it will have on the labor market. Where do all the "disposed" workers end up ? Some youth may go back to school, but ought to reappear after few years (which does not seem to be the case). A number of young entrants move into the black economy (by definition, unobservable, the order of magnitude estimated by ISTAT at $15-20 \%$ of the labor force). Few are hired each year in the nonobservable public sectors (military or police service); the same holds for the university graduates who move directly in professional independent activities.

A similar, preliminary, exploration in Norway and Denmark indicates that the pseudo-survival rate 10 years after entry is between 90 and $95 \%$ of the initial lot. Suggesting that the institutional setting explains such a huge difference may be true, but won't tell what is behind the story. This exploration is the first attempt in this direction.

An important result - not yet an explanation - indicates that these estimates, at first sight dramatic, are consistent with an "extended" definition of unemployment that includes the individuals who belong to the irregular (undetectable) sectors of the economy. Which does not reduce the seriousness of the problem, and the difficulty of formulating policy recommendations.

The paper is organized as follows: par. 2 provides the background picture with a short description of the Italian labor market. Par. 3 describes the WHIP data coverage and how to bypass some of its shortcomings. The estimation of pseudo-

\footnotetext{
${ }^{3}$ The survival perspective of the self-employed will be the object of a separate investigation.

${ }^{4}$ A similar finding on UK data is reported in Stewart, Mark B \& Swaffield, Joanna K, 1999. "Low Pay Dynamics and Transition Probabilities", Economica, vol. 66 (261), pages 23-42, February.
} 
survival is the object of Par. 4. Par. 5 shows some unexpected gender differences in pseudo-survival. A quasi-Markov chain representation of the process of workforce disposal is presented in par. 6, confirming that the estimates of pseudosurvival are consistent with the indications of the official LFS. Descriptive statistics on age wage differentials are provided in par. 7. A regression model aimed at explaining the short-medium run features of pseudo-survival is the object of par. 8. Non-parametric (diff-in-diff) estimators of the net impact of labor costs on survival are presented in par. 9. Par. 10 deals with the problem of self-selection and its possible impact on our results. Par. 11 concludes.

\section{Background}

According to official statistics, Italy's unemployment rate of the 14-29 has hovered around $20 \%$ for many years, the second highest in the European Union. Long term unemployment touches $2 / 3$ of the unemployed. Not until $2006 \mathrm{did}$ youth unemployment take a downturn of 2-3 p.p., matched, not surprisingly, by an increase in turnover rates.

In Italy youth employment (20-29) steadily increased since the Sixties til 1990 (from 4.0 million in 1968 to slightly less than 5.0 million in 1990), a consequence of the baby boom and of the increased participation of young women. The trend dramatically reversed in the early Nineties before the 1993 recession: in 2002 dependent employment of the young was back to the level of the mid Seventies, in spite of: (1) several programs aimed at enhancing labor market entry since the mid Eighties; (2) the new cohorts shrank from 900,000 during the baby boom to 500,000 nowadays.

The modal age of employment entry hovered around 21 for many years: since the Nineties the outflow of young workers from employment began to exceed the inflow within 3-4 years from entry. Net employment flows turned negative, suggesting that the "disposable" pattern of labor force utilization was already well under way before the cyclical downturn.

Labor market entry at the end of school is problematic too, compared to EU standards: the one-year transition probability for youth aged (15-19) is estimated at 0.54 from the Italian LFS, implying an average delay of 2 years after school termination. The same probability at age (20-24) is 0.69 , and at age (25-29) is 0.70 . University graduates (first level degree) face a 8.5 months average waiting time before finding a job, from a minimum of 5 months for engineering graduates and a maximum of 13 months for jurisprudence graduates. The average 
unemployment rate for university graduates 3 years after the end of studies exceeds $8 \%{ }^{5}$.

The labor market reforms of the last twenty years - leading to a variety of increasingly flexible working arrangements - have changed this picture only to a limited extent. After the introduction of the CFL (contratti di formazione e lavoro, 1984) and the Pacchetto Treu (1996), which extended the utilization of temporary contracts, worker turnover among the young increased only marginally. Prior to those years, it was common practice to terminate working contracts (not only of the young) circumventing a legislation which was very protective on paper, but easily bypassed in practice (as jurists put it, the "law in the books" is one thing, the "law in action" quite another matter). The reforms have, as it where, legalized a good many of those terminations.

Fig. 1 below shows the increasing trend of separation rates from standard, open-end positions in the 1986-2003 time window. There is a sudden increase of young workers' separations starting in 1994, two years before the Pacchetto Treu.

Tab. 1 displays the labor market status of individuals aged 16-35, four years after termination of their first employment experience: only in $25 \%$ of cases this was a permanent position. One half of all individuals are found in a permanent, open-end position after 4 years. More than one third are on atypical contracts. And even among those who had a standard, permanent contract as their first job, over one fourth have switched to atypical contracts.

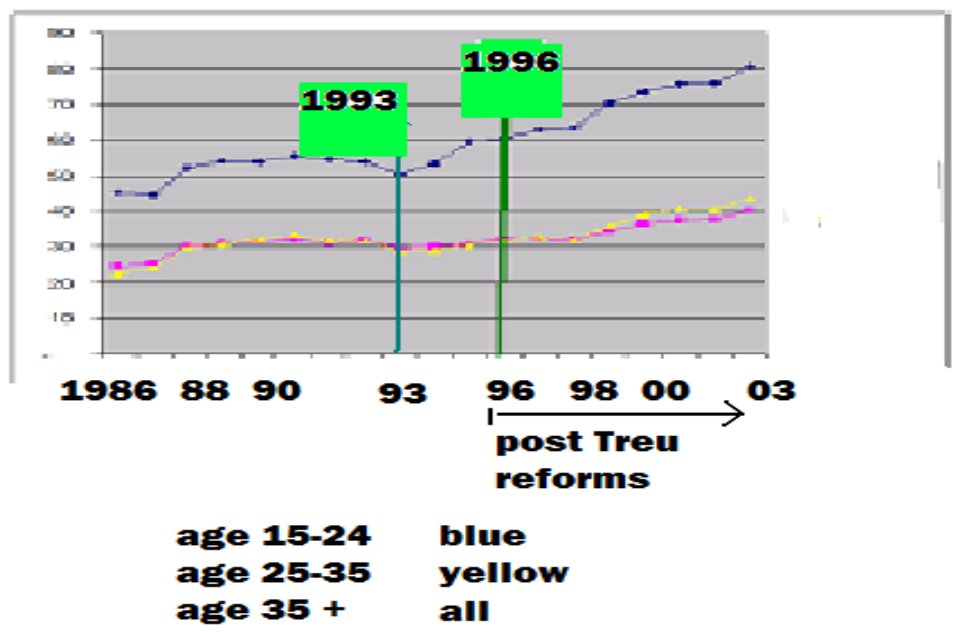

Fig.1 Separation rates from standard, open-end positions 1986-2003

\footnotetext{
${ }^{5}$ All the data of University graduates come from the Alma Laurea Survey 2007 and refer to graduation earned in 2006.
} 
Tab. 1: \% Working contract 4 years after first contract termination in 1998-99 (age 16-35 at entry)

\begin{tabular}{|c|c|c|c|c|c|c|}
\hline $\begin{array}{l}\text { First } \\
\text { employment } \\
\text { contract }\end{array}$ & $\begin{array}{l}\text { Number of } \\
\text { contracts }\end{array}$ & $\%$ & $\begin{array}{l}\text { Unemployed or } \\
\text { OLF }\end{array}$ & $\begin{array}{l}\text { Standard } \\
\text { open-end } \\
\text { contract }\end{array}$ & $\begin{array}{l}\text { Atypical } \\
\text { contract }\end{array}$ & $\begin{array}{l}\text { Self- } \\
\text { employment }\end{array}$ \\
\hline Standard & 885 & 24.4 & 7.6 & 58.1 & 26.5 & 7.8 \\
\hline $\begin{array}{l}\text { Permanent part- } \\
\text { time }\end{array}$ & 204 & 5.6 & 13.7 & 39.7 & 38.7 & 7.9 \\
\hline $\begin{array}{l}\text { Training-and- } \\
\text { work (CFL) }\end{array}$ & 304 & 8.4 & 6.2 & 65.5 & 20.7 & 7.6 \\
\hline Apprentice & 920 & 25.3 & 8.0 & 38.9 & 45.9 & 7.2 \\
\hline $\begin{array}{ll}\text { Temp } & \text { (work- } \\
\text { leasing) }\end{array}$ & 146 & 4.0 & 4.1 & 66.5 & 25.3 & 4.1 \\
\hline Seasonal & 118 & 3.2 & 11.0 & 43.2 & 39.0 & 6.8 \\
\hline Temporary & 587 & 16.2 & 7.7 & 53.8 & 33.9 & 4.6 \\
\hline $\begin{array}{ll}\text { Disguised self- } \\
\text { employed. } \\
\text { ("gestione } \\
\text { separate") }\end{array}$ & 433 & 12.0 & 8.5 & 37.0 & 46.5 & 7.9 \\
\hline Self-empl. & 38 & 1.1 & 5.3 & 42.1 & 15.8 & 36.8 \\
\hline ALL & 3635 & 100.0 & 8.0 & 50.1 & 34.4 & 7.5 \\
\hline
\end{tabular}

Source: F. Berton, M. Richiardi, S. Sacchi (2008), p.122

The next graph (fig. 2) shows the new entries in the labor market in the 1986-2002 period: the dotted line displays the newly hired whose first initial spell lasted at least 12 months, the thick one those whose initial spell lasts less than 3 months. The upper graph depicts the age-group 25-30; the lower one the group (19-22). The number of "long" initial spells declines rapidly after peaking 2-3 after 1986. The number of "very short" ones increases throughout the whole period for the 25-30 group, and until 1994 for the younger age group, after which it tapers off and then slightly declines. Throughout the Eighties many of the newly hired were able to stay with their first employer at least one year before undertaking a pattern of mobility; and very short initial spells were relatively rare. We are therefore facing an unambiguous signal of increased mobility at the beginning of one's career, which persists at all ages.

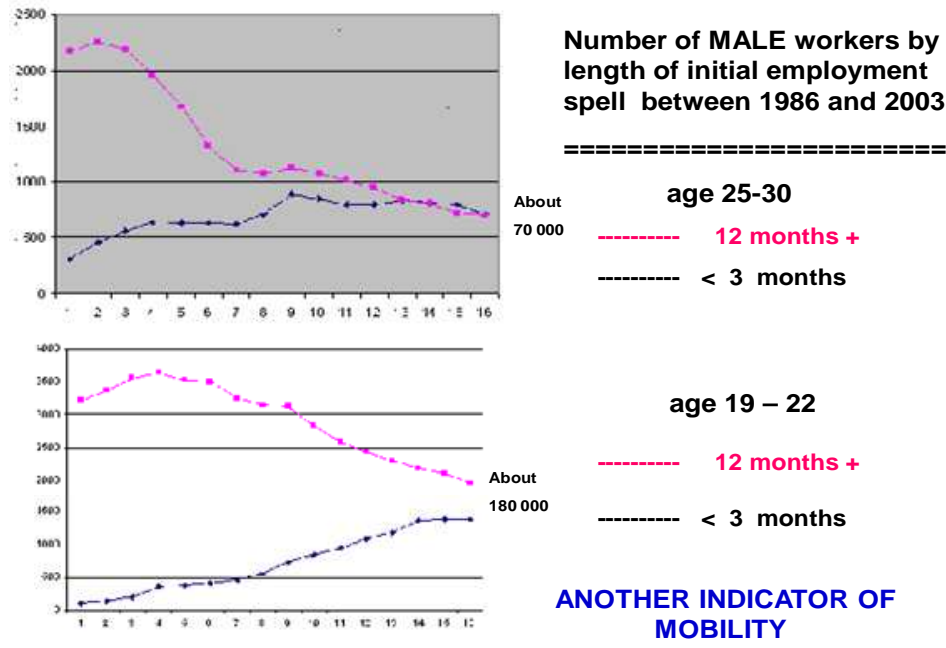

Fig. 2 No. workers by length of initial employment spell 1986-2003. 
On paper the Italian labour market presents a high degree of employment protection. Protection, however, turns out to be mainly "in the books", much less so "in action". Such questions as "are the dismissed ones eligible for unemployment benefits?", "does the previous employment experience of laid off workers permit a fast re-employment ?", are negatively answered and cogently discussed in a recent book by F. Berton, M. Richiardi and S. Sacchi. ${ }^{6}$

The probability of becoming trapped in long term unemployment has been the object of recent investigation by Contini \& Poggi (2009): unemployment state dependence is estimated at $61 \%$, a very high estimate compared to most other EU countries, and - as elsewhere - is negatively correlated with initial wages.

\section{The WHIP data and coverage}

The WHIP longitudinal data are a representative sample of the population of employees of the private sector, the self-employed, as well as all those covered by atypical (non-standard) contracts. The sample - population ratio is 1:90. WHIP observations start in 1986 and, as of today, end in 2004. The next update of the sample will soon be available and take us through 2008.

For the purpose of this exploration the (existing) data of the "contratti di collaborazione", a widely used atypical form of disguised self-employment, cannot be used. All our conclusions, however, would be robustly strengthened if such data were available. The atypical contracts apply, among many others, to the public sector employees with non-tenured positions. WHIP does not cover tenured employees of the public sector (including the military service and the police), nor the professionals working on their own. As will be argued, this is a relatively minor problem for an exploration like this, targeted at young people. In addition, the WHIP data do not provide information on the unemployment status unless individuals receive unemployment benefits (an unlikely event under current Italian legislation. Protection against temporary layoffs is offered by the Earnings Integration Fund (Cassa Integrazione Guadagni ) which is observed in the WHIP database.

A problem of self-selection could be raised in connection with our measurement of "disposable" workforce. The individuals whom we consider "disposed" once they leave the panel and are no longer observable could, in principle, be entering the world of big business (excluding self employment, which we do observe and account for), or the professions, on a path of upward mobility. There are reasons to believe that the problem is negligible, and that none

\footnotetext{
${ }^{6}$ Flex-insecurity:perchè in Italia la flessibilità diventa precarietà, Il Mulino (2009)
} 
of our results would be harmed. The main one being that the vast majority of those who are "disposed" quickly do very poorly in terms of initial job tenure and pay. But there are many others. At any rate, I leave this defense to the last paragraph of the paper.

Also truncation at the end of the observation period could upward bias the estimate of workforce disposal for those entering in the late Nineties. This does not seem to be a major problem: the order of magnitude and characteristics of pseudo-survival in the first 5-7 years of career of those who entered the labor market in the mid Eighties is very similar to what is observed for the younger entries. In my judgment, the 8-10 year-absence of a young male from administrative files that cover the entire population of economically active people is more than sufficient to consider him "disposed".

The outflows of young people toward the public sector and the professional world can be estimated via the Alma Laurea Yearly Survey of Italian University graduates (tab. 2) ${ }^{7}$ :

Tab. 2 Alma Laurea Survey 2006 : the destination of University graduates

\begin{tabular}{|c|c|c|c|c|c|c|}
\hline Fields & $\begin{array}{l}\text { No. } \\
\text { university } \\
\text { graduates } \\
\text { per } \\
\text { year }\end{array}$ & $\begin{array}{l}\% \text { professionals } \\
5 \text { years after } \\
\text { grad. }\end{array}$ & $\begin{array}{l}\text { No. } \\
\text { professional } \\
5 \text { years after } \\
\text { graduation }\end{array}$ & $\begin{array}{l}\% \\
\text { atypical } \\
\text { contr. } 3 \\
\text { years after } \\
\text { grad. }\end{array}$ & $\begin{array}{l}\text { No. atypical } \\
\text { contracts } 3 \\
\text { years after } \\
\text { grad. }\end{array}$ & $\begin{array}{l}\% \\
\text { Public } \\
\text { Sector } \\
3 \text { yrs } \\
\text { after } \\
\text { grad. }\end{array}$ \\
\hline Engineering & 3500 & 16 & 560 & 11 & 400 & 250 \\
\hline $\begin{array}{l}\text { Medical } \\
\text { School }\end{array}$ & 2100 & 54 & 1130 & 36 & 750 & 500 \\
\hline Humanities & 5000 & 0 & 0 & 48 & 2500 & 750 \\
\hline Law & 4900 & 8 & 400 & 18 & 900 & 700 \\
\hline Architect. & 1600 & 50 & 800 & 19 & 320 & 120 \\
\hline Psychology & 1400 & 16 & 200 & 34 & 450 & 300 \\
\hline $\begin{array}{ll}\text { Economics } & \& \\
\text { Business } & \\
\end{array}$ & 4900 & 2 & 100 & 15 & 750 & 390 \\
\hline Total & 23400 & 13.6 & 3190 & 25.9 & 6070 & 3010 \\
\hline
\end{tabular}

About 9\% of university graduates are unemployed 1 year after graduation, and the waiting time before the first job is 8,5 months. At least $26 \%$ of university graduates work as "disguised self-employed" 3 years after graduation (certainly a lower bound, as some fields are missing from the table, all of them leading to less upward mobility than the ones included). It is a very safe guess estimating that at least $2 / 3$ of all the university graduates are hired via atypical contracts (about 16000 individuals/year). Professionals are not observed in WHIP. But the university graduates who are in the professions 5 years after the end of studies

\footnotetext{
7 The Alma Laurea Survey covers all Italian Universities except Rome and Milan (which, alone, account for $30 \%$ of all University graduates). Tab.2 includes estimates of Rome and Milan, according to the proportions of the Survey..
} 
number about 3200 , on average 160 entries each year ${ }^{8}$. All of them begin their career in professional studies, hired - another safe guess - with non-standard contracts. Alma Laurea indicates also that over $25 \%$ of all university graduates move into the public sector within 3 years from graduation. But it is a well known fact that all the young hires of the Italian public sector have taken place via atypical contracts at least since the late Eighties. Very few, very lucky ones will be granted tenure after 2-3 years. The vast majority will have to wait $8 / 10$ years, and until then they will be observed in WHIP ${ }^{9}$. Once they move into tenured positions they will be well in their thirties, no longer relevant for this exploration.

\section{Estimating pseudo-survival}

The analysis is performed on cells of individuals of the same gender, belonging to the same cohort and who had their first job in the same year, to the same industrial branch (manufacturing and services) and geographical area (Northern, Central, and Southern Italy). The length of the initial employment spell is an additional dimension ( $<3$ months, 3-12 months, $>12$ months).

In most of the analysis we deal with thousands of cells, each observed at one-year distance from 1986 through 2002. In some cases we also disaggregate cells by size of the first employer (small $=<20$ employees; medium $=20-200$; large $=200+$ ). Each cell includes from a minimum of 18 to a maximum of 1089 individuals.

Survival is estimated in each cell counting the number of individuals who have not disappeared from the database at the end of the observation period. Fig. 3 describes the counting methodology: it shows one cell containing the work histories of 8 individuals, A through $\mathrm{H}$, observed between 1986 (year of entry for all) and 2008:

\footnotetext{
8 It is, obviously, more likely that those who move into the world of professionals will do so 4-5 years after graduation, rather than 1-2 years. But the substance does not change.

9 In WHIP the "instruction" activity sector includes teachers of both public and private schools. As said before, public school personnel is observed if non- tenured. In Italy the proportion of public school teachers and employees to private school employees is about 10:1. From WHIP we observe $50 \%$ of all school personnel below 30 years of age; $63 \%$ of those below 28, over $20 \%$ below $40.90 \%$ are public employees, all queuing for tenure.
} 


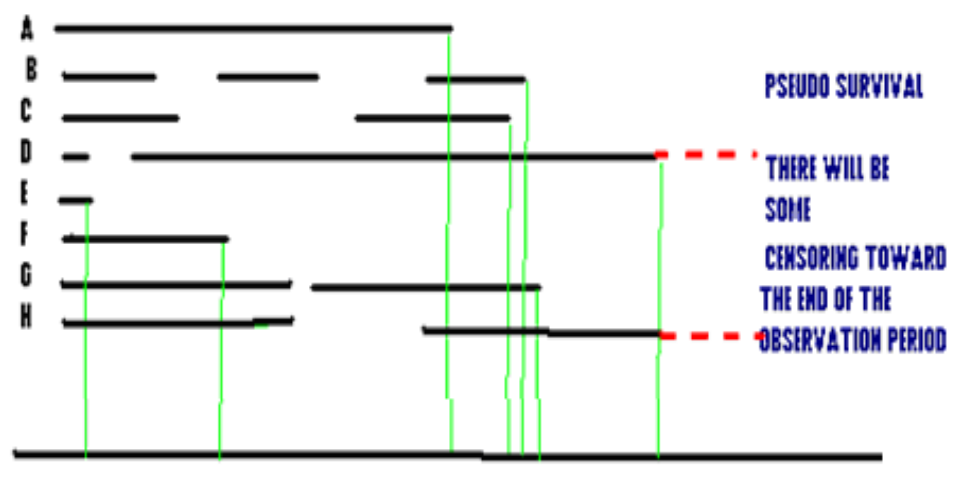

868788899091929394959697989920000102030405060708

[

Fig.3 Counting pseudo survival.

Let the survival count take place in 2008. In year 1993 we count the following survivors: A, B, C, D, F, G and $\mathrm{H}$ (yielding a survival rate $=7 / 8=$ 0.875 ), as $\mathrm{E}$ has exited two years after entry and no longer reappears. In year 2000 the following have survived: $\mathrm{A}, \mathrm{B}, \mathrm{C}, \mathrm{D}, \mathrm{G}$ and $\mathrm{H}$, yielding a survival equal to $6 / 8$ $=0.75$. Notice that, as the count is done in 2008, individual B is counted as survivor through 2003, as he did go into unemployment (extended version) between 1991 and 1993, and between 1997 and 1999, but his working career continues at least until 2003. Obviously, in 2008 he could find himself in a long spell of unemployment whose ending will occur years later. If that were the case, our survival count in 2003 would be downward biased. This is the truncation problem that we (partially) avoid by restricting the observation window to 1998 , which leaves 6 extra years before truncation. The complete count through 1998 would lead to the following survival curve:

\begin{tabular}{|l|l|l|l|l|l|l|l|l|l|l|l|l|}
\hline 1986 & 87 & 88 & 89 & 90 & 91 & 92 & 93 & 94 & 95 & 96 & 97 & 98 \\
\hline 1 & 1 & $7 / 8$ & $7 / 8$ & $7 / 8$ & $7 / 8$ & $7 / 8$ & $7 / 8$ & $6 / 8$ & $6 / 8$ & $6 / 8$ & $6 / 8$ & $6 / 8$ \\
\hline OUT & -- & $\mathrm{E}$ & $\mathrm{E}$ & $\mathrm{E}$ & $\mathrm{E}$ & $\mathrm{E}$ & $\mathrm{E}$ & $\mathbf{E}, \mathbf{F}$ & $\mathbf{E , F}$ & $\mathbf{E , F}$ & $\mathbf{E , F}$ & $\mathbf{E , F}$ \\
\hline
\end{tabular}

Fig. 4 depicts a prototype of pseudo-survival curve, aimed at showing the main differences that emerge on impact. The first one is attributable to the length of the first employment spell. Out of 100 new entries with initial employment spell < 3 months, approximately 60 survive 10 years after entry. If the initial employment spell > 12 months, the 10-year survival rate is 86 . 
SURVNL PATTERNS:

ARE YOUNG PEOPLE'S JOBS BECOMING A

DISPOSABLE COMMODITY?

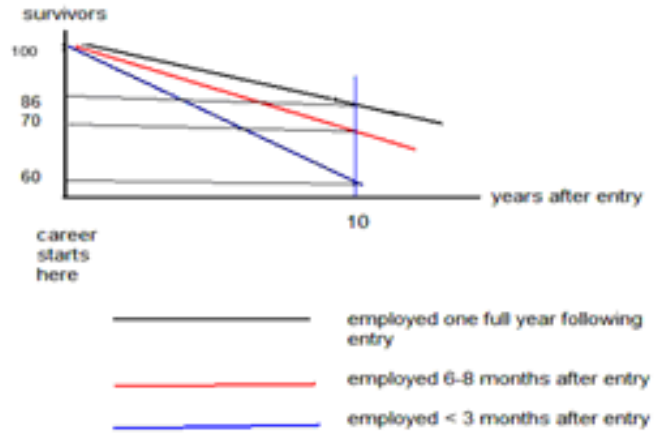

Fig. 4 Patterns of pseudo-survival.

Several additional factors determine survival. One is the timing in the business cycle of labor market entry: if the initial job starts in expansionary years, the survival is likely to be higher than if the working career begins during recession times. The geographical area makes some difference, and so does the industry. Simple econometric explorations yield several results to which I shall return in due time.

For the time being, let it be clear what these pseudo-survivals imply and what they don't imply: the above 60 survivors (with initial job spell $<3$ months) are not people necessarily at work for 10 consecutive years: they may have had alternating employment and non-employment spells in the 10-year period, but have re-entered employment at the end of the 10-th year of observation. We are dealing with a process of in-and-outs of employment, which, in principle, might involve equally all the new entries as in a big job sharing experiment, each working $60 \%$ of the time and being idle the remaining 40\%. Not unexpectedly, this is not the case of Italy (nor, for that matter, of any other country, the Netherlands being the only possible outlier). 

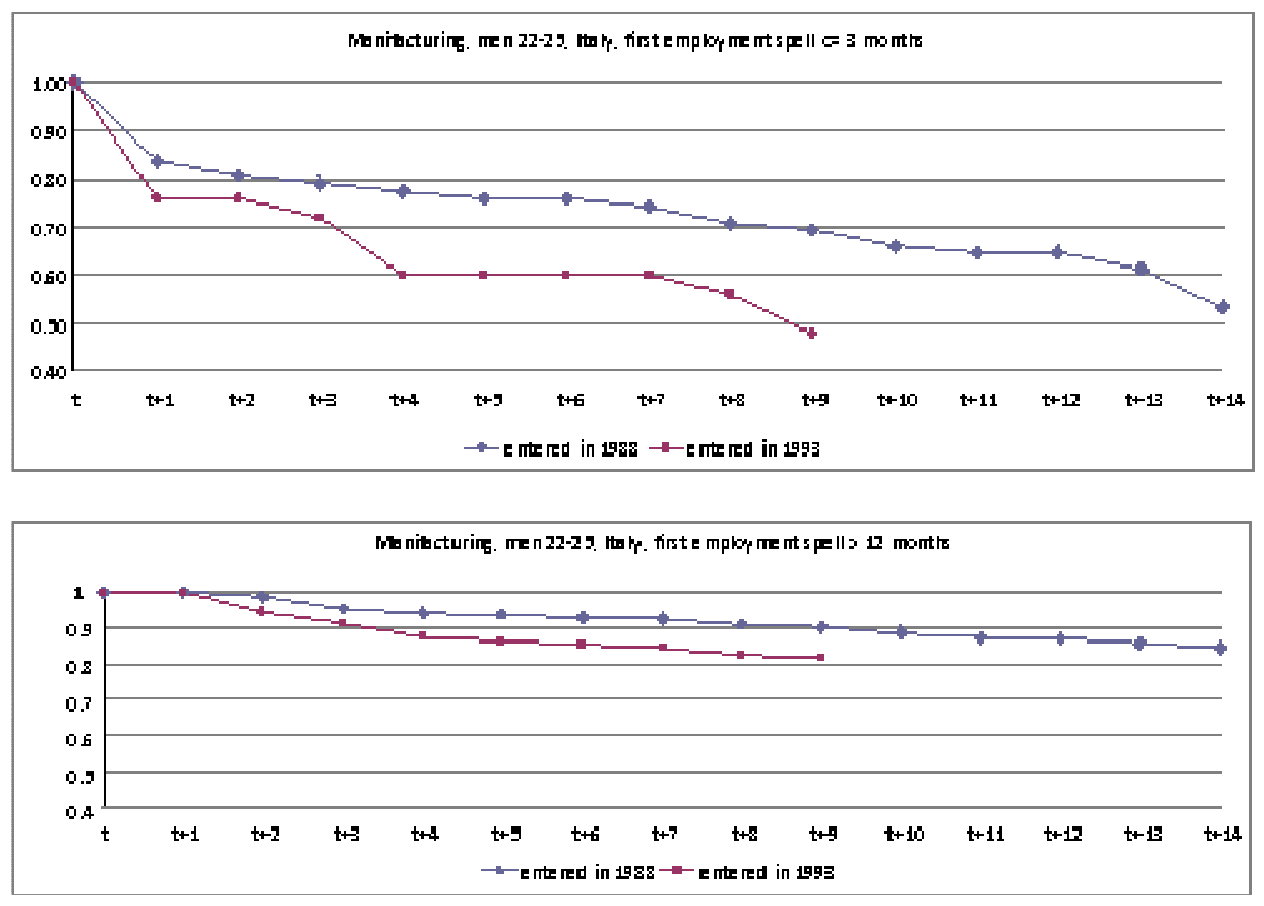

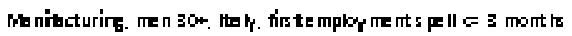

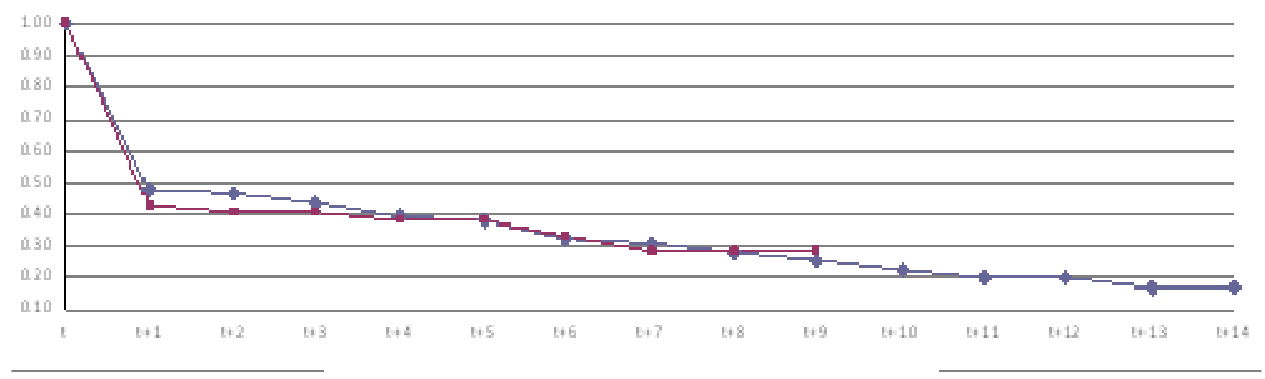

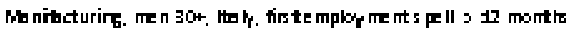

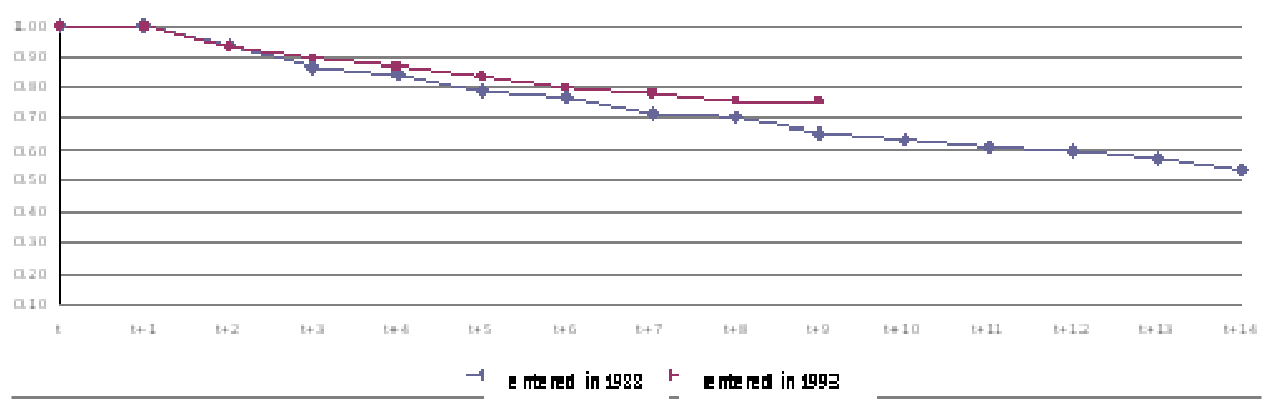



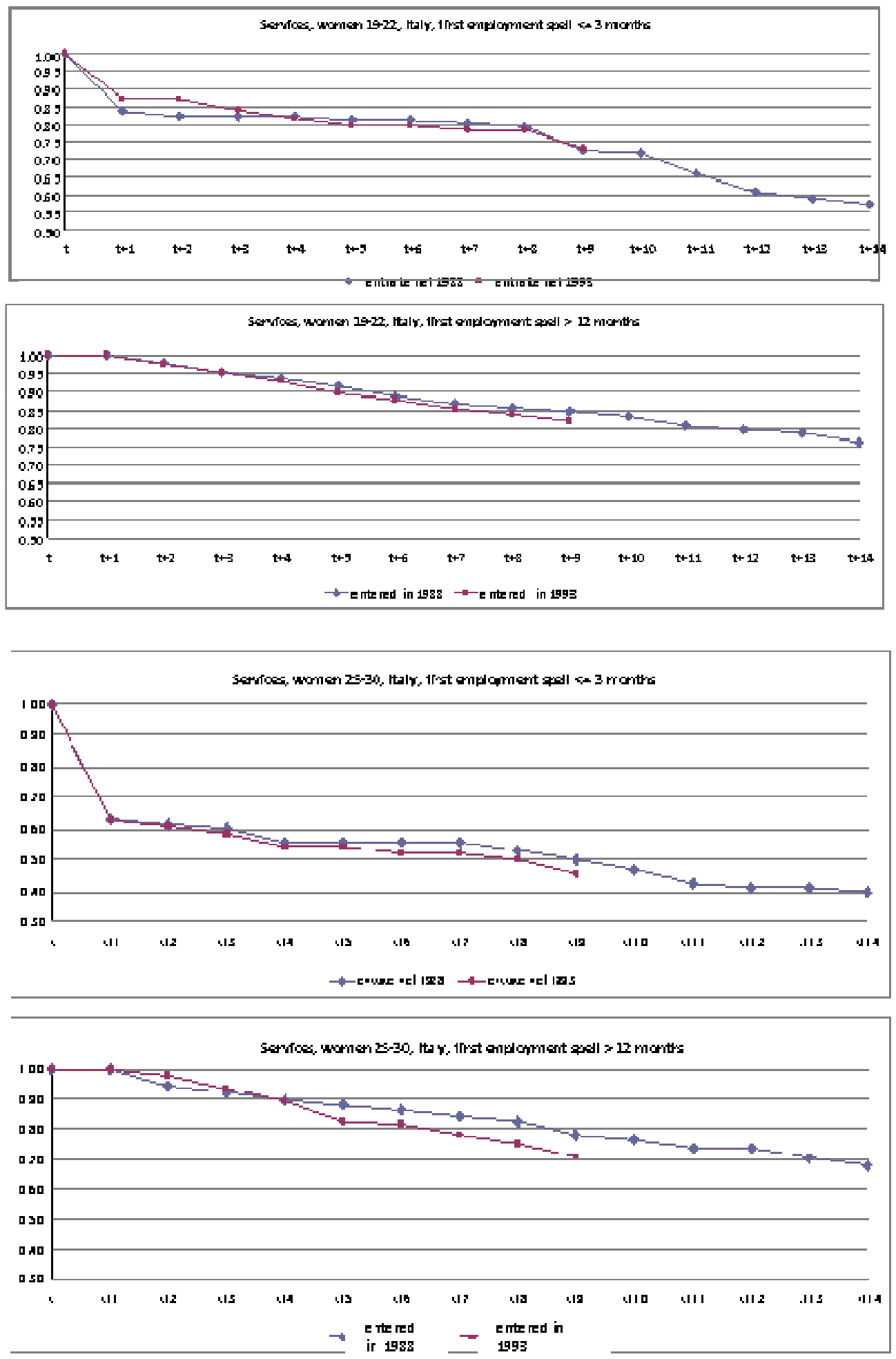

Fig. 5.1 -5.4 Pseudo-survival curves for selected cohorts and year-of-entry.

A few selected pseudo-survival curves are displayed in fig.5.1-5.4. Each figure shows the pseudo-survival measured in cells composed of individuals of same gender, age group (at the time of first job), geographical area and economic 
branch. The upper graph refers to cohorts who experienced a very short employment spell ( $<3$ months), the lower one to the same cohorts with a long spell (> 12 months). In addition, two cohorts are compared in the same graph: the dotted line refers to cohorts who first entered in 1988 (expansionary cycle), and are followed till $(t+14=2002)$, the thick one refers to entries of 1993 (recessionary), followed till $(t+9=2002)$. The impact of the first spell duration is very clear: an immediate drop of survival in $(t+1)$ and $(t+2)$, followed by a continuing relatively steep fall. The impact of the business cycle on survival is also visible: the fall is usually steeper for the cohorts entering in 1993. Less clear, at first sight, is the impact of the age group and that of the sector of economic activity. Important differences will emerge as we turn to regression analyses.

\section{Women do better than men...}

The survival data of young women indicate that women at early age do better than men ${ }^{10}$ : tab. 3 compares male and women of two age groups, entering the labor market at three different points in time: 1988 at the beginning of an expansionary cycle, 1992 at the start of the recession of the Nineties, and 1996 at the end of the downturn. Attrition is measured 3, 7, 11 and 15 years after entry. The bold figures denote where women's survival is higher than men's: this is always the case in the younger group (19-22) at $t+3$ and $t+7$, i.e. until the included individuals reach the age of 22-25 and 26-29 respectively. It also occurs in the course of the recessionary years 1992-96 in the older age group (26-30), again at $\mathrm{t}+3$ at age 29-32, and at $\mathrm{t}+7$ at age 33-37. Men's survival becomes higher as women reach the age of child bearing and family chores. Surprisingly, however, the differences are smaller than one might expect: for instance, in 2003, $t+15$ for those who had their first work experience in 1988, attrition rates of the age group by then (41-45) is 0.56 for men and only 0.57 for women. This phenomenon, which may hide composition effects attributable to the specific industries where people are employed, is worth deeper investigation which must be left for another occasion.

\footnotetext{
10 The longer survival of young women in Italy and Germany has been noticed also in a recent paper by G. Giannelli, U. Jaenichen and C. Villosio, "Have labour market reforms at the turn of the millennium changed job durations of the new entrants?", W.P. LABOR (2009).
} 
Tab. 3.1: Male dependent workers $=\%$ no longer at work t years after entry

\begin{tabular}{|l|l|l|l|l|l|l|l|l|l|l|l|l|}
\hline age & $(0)$ & +3 & +7 & +11 & +15 & $(0)$ & +3 & +7 & +11 & $(0)$ & +3 & +7 \\
\hline $19-22$ & entry & .18 & .26 & .34 & .43 & entry & .19 & .29 & .42 & $\begin{array}{l}\text { entry } \\
19\end{array}$ & .17 & .34 \\
& 1988 & & & & & 1992 & & & & & & \\
\hline $26-30$ & 1988 & .24 & .35 & .44 & .56 & 1992 & .29 & .41 & .52 & 1996 & .28 & .40 \\
\hline
\end{tabular}

Tab. 3.2: Female dependent workers $=\%$ no longer at work t years after entry

\begin{tabular}{|l|l|l|l|l|l|l|l|l|l|l|l|l|}
\hline age & $(0)$ & +3 & +7 & +11 & +15 & $(0)$ & +3 & +7 & +11 & $(0)$ & +3 & +7 \\
\hline $19-22$ & entry &. $\mathbf{1 5}$ &. $\mathbf{2 4}$ & .35 & .47 & entry &. $\mathbf{1 5}$ & $\mathbf{. 2 7}$ & .45 & entry & $\mathbf{. 1 5}$ & $\mathbf{. 3 3}$ \\
& 1988 & & & & & 1992 & & & & 1996 & & \\
\hline $26-30$ & 1988 & .27 & .38 & .48 & .57 & 1992 & .27 & $\mathbf{. 3 9}$ & .55 & 1996 & .29 & .47 \\
\hline
\end{tabular}

\section{A quasi-Markov chain representation of the youth labor market}

The youth labor market lends itself to a representation in terms of a quasiMarkov chain ${ }^{11}$. The chain is defined by states that correspond to employment and "extended" unemployment of different durations: one-year employment, morethan-one-year employment, one-year unemployment, two-year unemployment, more-then two-years unemployment. Transition probabilities are estimated on the basis of a standard logit model à la Heckman on individual careers of male workers aged 16-29 $9^{12}$ Transitions are allowed only between time-contiguous states:

\begin{tabular}{|l|l|l|l|l|l|}
\hline from / to & $\mathrm{U} 1$ & $\mathrm{U} 2$ & $\mathrm{U} 2+$ & $\mathrm{E} 1$ & $\mathrm{E} 2+$ \\
\hline $\mathrm{U} 1$ & 0 & 0.60 & 0 & 0.4 & 0 \\
\hline $\mathrm{U} 2$ & 0 & 0 & 0.85 & 0.15 & 0 \\
\hline $\mathrm{U} 3+$ & 0 & 0 & 0.93 & 0.07 & 0 \\
\hline E1 & 0.05 & 0 & 0 & 0 & 0.96 \\
\hline E2+ & 0.04 & 0 & 0 & 0 & 0.96 \\
\hline $\begin{array}{c}\text { Steady-state } \\
\mathrm{U}=27 \%\end{array}$ & 0.03 & 0.02 & 0.22 & 0.03 & 0.70 \\
\hline
\end{tabular}

\footnotetext{
${ }^{11} \mathrm{~A}$ quasi-Markov chain is defined as a process in which states may not be of equal length. Transitions are estimated as usually, and the steady state is calculated and interpreted as in any Markov chain, but a concept like the mean recurrence time is no longer applicable.

${ }^{12}$ See B. Contini and A. Poggi (2008).
} 
The steady state distribution of the above matrix (reached in 6-7 iterations from a starting position close to the one observed in the late Nineties) yields the following result: $73 \%$ of the workforce in employment (70\% in more-than-oneyear positions E2+); $27 \%$ unemployed, extended definition (of which $22 \%$ in long term unemployment $\mathrm{U} 3++$ ). The steady state unemployment figure is 6-8 p.p. higher than the official youth unemployment rate at the beginning of the Millennium: this difference is coherent with the hypothesis that over 200 thousand young men may be hidden in the irregular sectors, without any presence in the official economy ${ }^{13}$, and therefore undetected in the Labor Force Survey. The 200 thousand - figure is reached as follows: 6-8 p.p. of the male workforce aged 16-24 (population 4.2 million, participation rate $30 \%=1.2$ million workforce) yields 100 thousand individuals. 6-8\% of the male workforce 25-29 (population 2 million; participation $60 \%=1.2$ million workforce), yields the remaining 100 thousand ${ }^{14}$. The figure of 200 thousand male individuals (16-29) is a conservative estimate of the presence of young men in the black economy, estimated at least $15 \%$ of total labor force according to official statistics.

The quasi-Markovian representation allows to estimate also the impact of public programs aimed at increasing the job finding rate of young people. An unrealistically effective labor exchange might increase it by $20 \%$ starting from U1 and $\mathrm{U} 2$, somewhat less from $\mathrm{U} 3+$. The new transition matrix looks as follows:

\begin{tabular}{|l|l|l|l|l|l|}
\hline from / to & U1 & U2 & U3+ & E1 & E2+ \\
\hline U1 & 0 & 0.52 & 0 & 0.48 & 0 \\
\hline U2 & 0 & 0 & 0.82 & 0.18 & 0 \\
\hline U3+ & 0 & 0 & 0.92 & 0.08 & 0 \\
\hline E1 & 0.05 & 0 & 0 & 0 & 0.96 \\
\hline E2+ & 0.04 & 0 & 0 & 0 & 0.96 \\
\hline $\begin{array}{l}\text { Steady-state } \\
\text { U }=20.4 \%\end{array}$ & 0.036 & 0.020 & 0.148 & 0.040 & 0.756 \\
\hline
\end{tabular}

\footnotetext{
${ }^{13}$ Excluding, therefore, people who work for black money, in addition to holding a regular job (for instance a blue-collar at Fiat who rounds the budget doing plumbing maintenance during the week-ends).

Furthermore, the earnings of criminal and/or mafia-type activities are often laundered / invested in "regular" covering businesses; thus, also outright criminals may appear as "regular" workers.

${ }^{14}$ The borderline between inactivity, unemployment without subsidies and irregular activities defies detection in the WHIP data, but similar problems arise also in LFS-type surveys, all the more so in areas where there is a considerable amount of black-grey (or next-to-criminal) activities. Here, a young male who reports to be working, may be a "regular" or an "irregular" worker. He may report to be unemployed even if he works full time in the black. Being classified as "inactive" or "unemployed" depends on the classification rules and the interpretation given to one's "recent" job search activity (see E. Battistin and E. Rettore, 2008). There is plenty of anecdotal evidence (to be taken very seriously) that many youth who work in the black economy will report themselves as unemployed or inactive. In the poorest neighbourhoods of Naples estimated youth unemployment is close to $40 \%$, with the extent of the black economy also known to be at its highest. The situation in the banlieus of Paris may not be too different.
} 
Its steady state distribution has $75.6 \%$ of the workforce in employment and $20.4 \%$ in extended unemployment: quite an improvement over the present situation. This is, however, only the estimated impact on the young: a necessary but insufficient information to formulate a judgement on the welfare benefits of the program. A higher take-up rate of workers aged 15-29 might, in fact, crowd out labor demand for cohorts aged $30+$, or for other segments of the labor force ${ }^{15}$.

\section{The increasing wage differentials between young and older workers}

Italy is following the world-wide trend of increasing wage differentials, attributable to the demand for high skills. Wage differentials between young and adult-older individuals have increased also independently from the skill component; and the reforms aimed at enhancing the job opportunities of young people - by introducing wage subsidies to employers - have had an additional effect of widening them. Tab. 4 displays mean and percentiles of the gross wage differential ratios between blue-collars, aged $<25$ and $>45$, regularly employed as dependent workers. In 1985 the mean ratio was 0.71 ; it steadily declined through 2003. We do not have systematic data of labor costs of some of the atypical contracts that have become popular in the last decade (in particular the "co.co.co" or "co.co.pro" contracts, both basically disguised self-employment contracts): undoubtedly, however, they would make the comparison look even less favorable for the young.

Tab. 4: Gross wage differentials young/adult workers

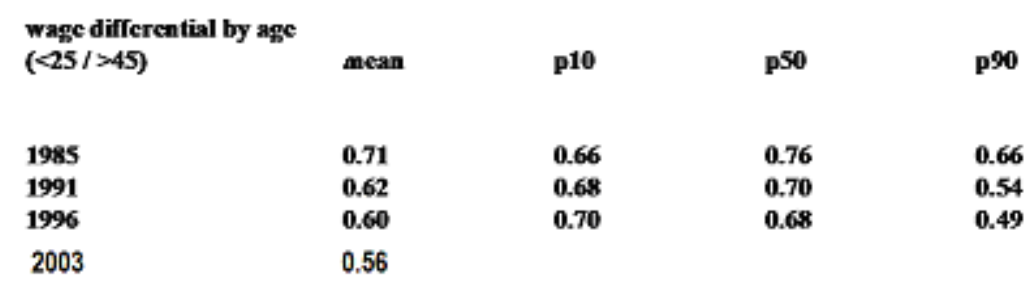

\footnotetext{
${ }^{15}$ In B. Contini et al. (2005) it was estimated that the CFL program (contratto di formazione e lavoro) for youth aged $<29$ had a non-negligible negative impact on the no-longer-eligible cohorts.
} 


\section{Regression estimates of the determinants of pseudo-survival ${ }^{16}$}

We estimate the determinants of pseudo-survival between-cells of individuals with very similar characteristics. Estimation on individual work histories is less advisable if a long term interpretation is desired. The number of observable, very homogeneous cells is high, which helps to bypass the problem of unobserved heterogeneity without harming the main results (heterogeneity gets averaged out across the individuals belonging to the cell).

Regressions on pseudo-survival ought to be done with care: all pseudosurvival schedules are monotonically decreasing in time, each having at most 17 time observations for the first observable labor market entries (1986), and only 7 for the most recent ones (1996). Therefore the introduction of too many dummies (some of which are necessary) will yield high R2, leaving little of substance to be explained.

It is therefore prudent to take first differences of pseudo survival and use these as dependent variables, rather than levels.

Cells are defined by the following items:

- $\quad$ age group of the relevant cohort (3 groups)

- $\quad$ gender

- $\quad$ year of first entry in the labor market (15 years, from 1988 to2001)

- duration of first employment spell (3 groups)

- $\quad$ economic branch of activity ( 2 industries)

- $\quad$ geographical area (3 areas)

- $\quad$ size of first employer (3 size groups)

The number of cells is 48600 (the product of all the above attributes): obviously, many are empty, and some include no more than 2 individuals. We have decided to retain only those with at least 4 individuals, which leaves over 3000 cells in Northern Italy and over 2500 in Southern Italy of male workers, and about $2 / 3$ as many of women.

Graphical exploration has already helped to single out two important factors: the duration of the first employment spell as a proxy of initial conditions, and the timing of labor market entry that catches the impact of the business cycle. Both have been used to define the cells. All the defining attributes enter as control regressors, altogether 19 dummy variables.

At least three additional factors ought to "explain" pseudo-survival:

- $\quad$ the growth rate of labor cost, specific to each age group ${ }^{17}$

- the inflows of potential competitors of different sex

\footnotetext{
${ }^{16} \mathrm{~A}$ simple model of labor demand for permanent vs. temporary working contracts provides the theoretical framework. It is briefly sketched in Appendix 2, entitled "A nutshell model of labor demand..."

17 Total labor cost includes social security contributions and other indirect elements, and is net of employer subsidies.
} 
- $\quad$ the youth participation rate as a proxy of labor supply.

Labor cost is the immediate benchmark that employers use to retain or layoff individual workers. My assumption is that it is a valid cost benchmark also at the level of the cells.
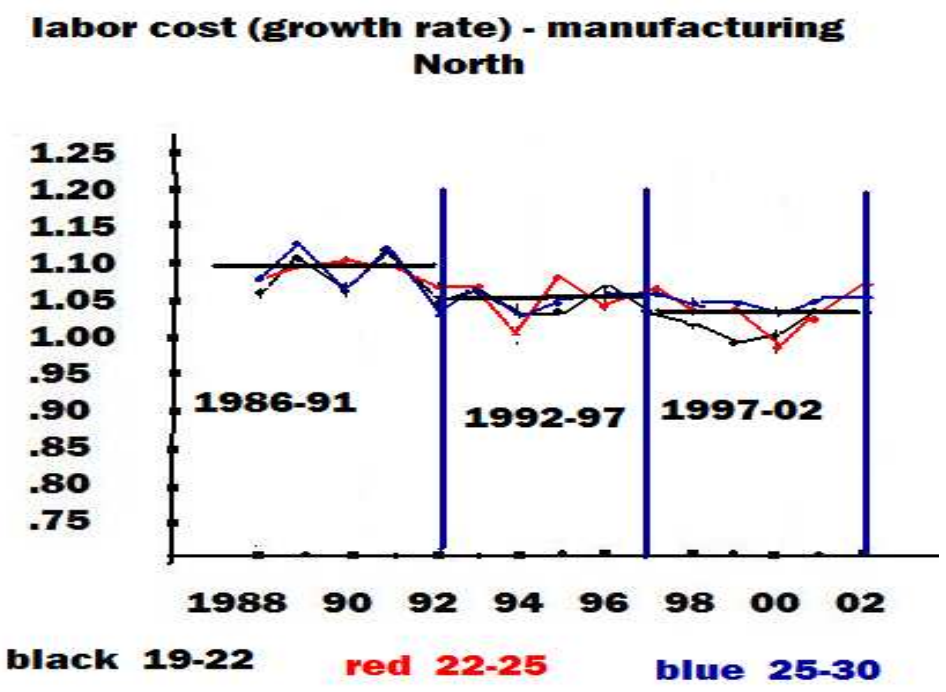

Fig. 6

Fig. 6 and 7 show the trends 1987-2002 of the rate of change of labor cost in manufacturing of Northern Italy and in the services of the South.. The variance of labor cost growth is higher in the service industries (not only in this example), and also among the youngest 19-22 age group, with more peaked spikes and troughs. The patterns are similar for all age groups in the North, less in the South. This is a consequence of programs of territorially-based employment subsidies (aimed at enhancing job creation of young people) that were implemented and phased out depending on the state of public finances. The observation period 1986-2002 suggests the following break-down of the cyclical phase: 1986-1991 expansion; 1992-1996 recession; 1998-2002 slow recovery. Both in the North and the South average growth of labor costs (the thick horizontal line within each of the three sub-periods) is higher in 1986-91 than in the next two phases. The 1992-96 average growth is still somewhat higher than that of the last cyclical phase in the North, and only marginally in the South. 


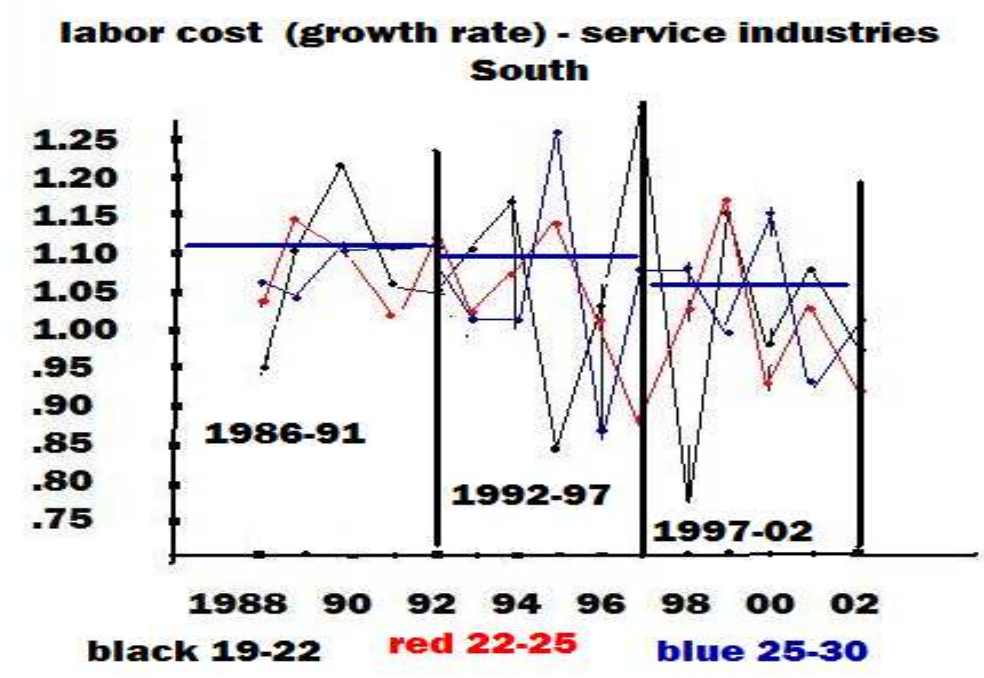

Fig.7

Women are important competitors of young males, especially in the whitecollar professions. We intend to estimate their impact on survival using the yearly employment inflows of women of all ages in the same industry and geographical area (ddonnentr).

Labor supply is proxied by the participation rate of young people (men and women, aged 15-24) in the relevant geographical area (dpart_giov).

The estimated specification is therefore:

$\Delta \operatorname{surv}(\mathrm{g}, \mathrm{t})=\mathrm{a}+\mathrm{b}^{*} \mathrm{~d}$-clav $(\mathrm{g}, \mathrm{t})+\mathrm{c}^{*}$ ddonnentr $(\mathrm{t})+\mathrm{d}^{*}$ dpart_giov $(\mathrm{t})+$ $\mathrm{e}^{*}$ all relevant dummies $(\mathrm{g})+\mathrm{u}(\mathrm{g}, \mathrm{t})$

where we expect: $b<0 ; c<0 ; d=?$.

For the time being we concentrate on male workers alone. We run 4 sets of regressions, separately for individuals working in manufacturing and service industries, located in Northern and Southern Italy. The building industry is left out for simplicity in order to avoid strongly seasonal components; Central Italy is also left out in order to focus on the main geographical differences between North and South. 
Tab. 6: Northern Italy-OLS (weighted). Regressions on a $\Delta$ pseudo survival

\begin{tabular}{|c|c|c|c|c|c|c|}
\hline Regr & $19-22$ & $19-22$ & $22-25$ & $22-25$ & $25-30$ & $25-30$ \\
\hline & Services & Mfg & Services & Mfg & Services & Mfg \\
\hline d-clav & $-.044 *$ & $-.089 *$ & $-.118 * *$ & $-.102 *$ & $-.126 * *$ & $.218 * *$ \\
\hline Dur 3-12 & $.026 * *$ & $.024 * *$ & $.018 *$ & .013 & $.012 *$ & .003 \\
\hline Dur $12+$ & $.045 * * *$ & $.063 * * *$ & $.035 * * *$ & $.054 * * *$ & $.043 * * *$ & $.045 * * *$ \\
\hline Med & -0 & .002 & 0 & $.008 *$ & .007 & 0 \\
\hline Big & -0 & $.008 *$ & 0 & $.013 *$ & 0 & .008 \\
\hline $\begin{array}{l}\text { Dum- } \\
\text { entry }\end{array}$ & Yes & Yes & Yes & Yes & Yes & Yes \\
\hline Donn_entr & 0 & 0 & 0 & 0 & 0 & 0 \\
\hline $\begin{array}{c}\text { Dpart_gio } \\
\mathrm{v}\end{array}$ & 0 & 0 & 0 & 0 & 0 & 0 \\
\hline $\mathrm{R}^{* * 2}$ adj & .19 & .17 & .10 & .09 & .10 & .08 \\
\hline n. obs & 1060 & 1078 & 1029 & 979 & 993 & 1028 \\
\hline
\end{tabular}

Tab. 7: Southern Italy - OLS (weigheted) regressions on $\Delta$ pseudo survival

\begin{tabular}{|c|c|c|c|c|c|c|}
\hline Regr & $19-22$ & $19-22$ & $22-25$ & $22-25$ & $25-30$ & $25-30$ \\
\hline & Services & Mfg & Services & Mfg & Services & Mfg \\
\hline d-clav & 0 & $-.113 *$ & 0 & $-.160 * *$ & $-.224 * *$ & $-.353 * *$ \\
\hline Dur 3-12 & $.016 *$ & .011 & $.019 *$ & .010 & 0 & .017 \\
\hline Dur $12+$ & $.040 * * *$ & $.066 * * *$ & $.043 * * *$ & $.043 * * *$ & $.033 * *$ & $\begin{array}{l}.061 \\
* * *\end{array}$ \\
\hline Med & 0 & .005 & .004 & $.010 *$ & $.012 *$ & .008 \\
\hline Big & 0 & $.019 *$ & $.011 *$ & $.027 * * *$ & $.019 *$ & $\begin{array}{l}.032 \\
* * *\end{array}$ \\
\hline Dum-entry & YES & YES & YES & YES & YES & YES \\
\hline Donn_entr & 0 & 0 & 0 & 0 & 0 & 0 \\
\hline Dpart_giov & 0 & 0 & 0 & $.005 * *$ & 0 & .003 \\
\hline $\mathrm{R} * * 2$ adj & .08 & .15 & .08 & .10 & .07 & .09 \\
\hline n. obs & 951 & 933 & 939 & 906 & 861 & 867 \\
\hline
\end{tabular}

Tab. 6 and 7 report the results of the weighted OLS regressions for each age group, activity branch and geographical area. ${ }^{18}$ Recall that, except for <dclav>,<ddonnentr> and <dpart_giov>, all regressors are dummy variables and therefore the coefficient estimates are measures of the impact of each on pseudosurvival. The results suggest the following:

the duration of the first employment spells (spells $<3$ months $=$ benchmark) strongly confirm the positive impact on survival noticeable also by visual inspection: up to 2 p.p. above the benchmark for the (3-12 months)-spells, higher in the services than in manufacturing; between 4 and 7 p.p. for the long (12 $+)$ - spells;

18 We cannot altogether exclude the endogeneity of the relative wage cost $\langle$ d-clav $\rangle$ (possibly jointly determined with pseudo-survival). We instrument <d-clav> with the various factors (dummies) used to build the cells, and re-estimate $\Delta$ survival by TSLS: none of the results that follow are affected by the procedure. Results are not displayed but are available on request. 
- $\quad$ firm size (benchmark = small) has some effect on survival in the manufacturing sectors of both North and South. Not unexpectedly, less in the services where small size is the exception aside from the banking industry. The larger is firm size, the higher the survival, with an impact which is higher in the South and varies between 1 p.p. to a maximum of 3 p.p.;

the regressions include the women inflows and the youth participation rates as regressors, but, with one exception, neither is significant. Apparently pseudo-survival seems unaffected by the inflows of workers who might be expected to be the "competitors" of young males;

labor cost growth (d-clav) is very significant, with the expected negative sign, except at age (19-22) in the service sectors of both North and South. The order of magnitude of the regression coefficient is between - .05 and -.35. This result needs clarification: the <d-clav> variable, by construction, has a modest variability around $1 .{ }^{19}$ It might, in principle, be collinear with the constant term. While multicollinearity is weakly rejected, omitting <d-clav> yields coefficients of all the regressors almost identical to the ones reported here, and also an overall fit - measured in terms of $\mathrm{R}^{* * 2} 2$ - somewhat lower;

the year of entry-dummies are almost always negative, although not necessarily significant: a plausible reflection of the fact that the benchmark 1987 was near the peak of the expansion in the second half of the Eighties;

\section{Estimating the impact of labor costs on 5-year survival}

I turn now to the impact of labor cost on pseudo-survival, net of business cycle effects. The break-down of the cyclical phase is the same as before.

The diff-in-diff approach is appropriate for the task. I consider survival 5 years from one's first job in the first two sub-periods 1986-1991 and 1992-1996, and 4 years from first entry in the last sub-period 1998-2002 (for lack of recent reliable data). The estimated pseudo-survival rates (based on the above regressions) are as follows:

$A=$ survival until 1991 for workers entered in 1986, measured at current labor cost;

B = survival until 1997 for workers entered in 1992, measured at current labor cost;

C = survival until 2002 for workers entered in 1998, measured at current labor cost; 1997

$\mathrm{D}=$ as in A, using a counterfactual labor cost $=$ average of period 1986-

\footnotetext{
${ }^{19}$ Using the growth rate of labor cost $(=\mathrm{d}$-clav -1$)$ would not solve the collinearity problem, as it has a small dispersion around 0 .
} 
$\mathrm{E}=$ as in $\mathrm{B}$, using a counterfactual labor cost $=$ average of period 1992-

$\mathrm{F}=$ as in $\mathrm{C}$, using a counterfactual labor cost $=$ average of period 19862002.

Then:

window

$(A-B)=$ average impact of business cycle cum labor cost in the 1986-1991

$(D-E)=$ average impact of business cycle in 1986-1991, at constant labor cost

$(A-B)-(D-E)=a v$. impact of labor cost in 1986-1991 net of business cycle effect.

$(B-C)=$ average impact of business cycle cum labor cost in the 19921997 window

cost

$(\mathrm{E}-\mathrm{F})=$ average impact of business cycle in 1992-1997, at constant labor

$(B-C)-(E-F)=$ av. impact of labor cost in 1992-1997 net of business cycle effect.

Consider the following example. In manufacturing (North), group (22-25), estimated 5-year survival after 1986 entry is $0.861(=\mathrm{A})$; the same after 1992 entry is lower $(\mathrm{B}=0.840)$. The gross impact on survival of the (expansionary) business cycle cum labor cost is positive and equal to 2.1 p.p. (=A-B). Estimated 5-year survival after 1986 entry at constant labor cost is $0.872(=\mathrm{D})$; the same after 1992 entry is $0.842(=\mathrm{E})$. The favorable business cycle, net of the impact of labor cost, accounts for 3.0 p.p. (=D-E), which is larger than the gross figure of 2.1 p.p. The diff-in-diff [(A-B-(D-E)] = 0.9 p.p. is the estimated net impact of labor cost. In spite of the slight decrease of the growth rate of labor cost between the expansion and the recession, its net impact is negative, i.e. the positive labor cost dynamics has not tempered the impact of the downturn on survival rates. 
Tab. 8: Estimated net impact of labor cost on pseudo survival

\begin{tabular}{|c|c|c|c|c|c|c|}
\hline \multirow[b]{2}{*}{ Area } & \multicolumn{6}{|c|}{ Northern italy } \\
\hline & Sector & Gender & Age & First spell duration & (A-B)-(D-E) & $(\mathrm{B}-\mathrm{C})-(\mathrm{E}-\mathrm{F})$ \\
\hline North & manifacturing & M & $19-22$ & $<=3$ & -0.0171 & -0.0130 \\
\hline North & manifacturing & M & $19-22$ & $3-12$ & -0.0187 & -0.0135 \\
\hline North & manifacturing & M & $19-22$ & $>12$ & 0.0017 & -0.0368 \\
\hline North & manifacturing & M & $22-25$ & $<=3$ & -0.0092 & -0.0099 \\
\hline North & manifacturing & M & $22-25$ & $3-12$ & -0.0092 & -0.0099 \\
\hline North & manifacturing & M & $22-25$ & $>12$ & -0.0092 & -0.0099 \\
\hline North & manifacturing & M & $25-30$ & $<=3$ & -0.0238 & -0.0201 \\
\hline North & manifacturing & M & $25-30$ & $3-12$ & -0.0238 & -0.0201 \\
\hline North & manifacturing & M & $25-30$ & $>12$ & -0.0238 & -0.0201 \\
\hline North & services & M & $19-22$ & $<=3$ & -0.0330 & 0.0123 \\
\hline North & services & M & $19-22$ & $3-12$ & -0.0330 & 0.0123 \\
\hline North & services & M & $19-22$ & $>12$ & -0.0330 & 0.0123 \\
\hline North & services & M & $22-25$ & $<=3$ & -0.0125 & -0.0147 \\
\hline North & services & M & $22-25$ & $3-12$ & -0.0125 & -0.0147 \\
\hline North & services & M & $22-25$ & $>12$ & -0.0125 & -0.0147 \\
\hline North & services & M & $25-30$ & $<=3$ & -0.0028 & -0.0171 \\
\hline North & services & M & $25-30$ & $3-12$ & -0.0028 & -0.0171 \\
\hline North & services & M & $25-30$ & $>12$ & -0.0028 & -0.0171 \\
\hline & & & & Southern Italy & & \\
\hline Area & Sector & Gender & Age & First spell duration & (A-B)-(D-E) & (B-C)-(E-F) \\
\hline South & manifacturing & M & $19-22$ & $<=3$ & -0.0120 & -0.0137 \\
\hline South & manifacturing & M & $19-22$ & $3-12$ & -0.0120 & -0.0137 \\
\hline South & manifacturing & M & $19-22$ & $>12$ & -0.0120 & -0.0137 \\
\hline South & manifacturing & M & $22-25$ & $<=3$ & -0.0083 & -0.0168 \\
\hline South & manifacturing & M & $22-25$ & $3-12$ & -0.0083 & -0.0168 \\
\hline South & manifacturing & M & $22-25$ & $>12$ & -0.0083 & -0.0168 \\
\hline South & manifacturing & M & $25-30$ & $<=3$ & -0.0148 & -0.0487 \\
\hline South & manifacturing & M & $25-30$ & $3-12$ & -0.0148 & -0.0487 \\
\hline South & manifacturing & M & $25-30$ & $>12$ & -0.0148 & -0.0487 \\
\hline South & services & M & $19-22$ & $<=3$ & -0.0056 & 0.0034 \\
\hline South & services & M & $19-22$ & $3-12$ & -0.0056 & 0.0034 \\
\hline South & services & M & $19-22$ & $>12$ & -0.0056 & 0.0034 \\
\hline South & services & M & $22-25$ & $<=3$ & 0.0014 & 0.0003 \\
\hline South & services & M & $22-25$ & $3-12$ & 0.0014 & 0.0003 \\
\hline South & services & M & $22-25$ & $>12$ & 0.0014 & 0.0003 \\
\hline South & services & M & $25-30$ & $<=3$ & -0.0281 & -0.0241 \\
\hline South & services & M & $25-30$ & $3-12$ & -0.0281 & -0.0241 \\
\hline South & services & M & $25-30$ & $>12$ & -0.0281 & -0.0241 \\
\hline
\end{tabular}

Tab. 8 displays the net impact on pseudo-survival of wage growth in the manufacturing and service sectors of Northern and Southern Italy respectively. The first column refers to the expansionary phase 1986-91; the second to the recessionary period 1992-96. As it has been already pointed out, average labor cost has slightly declined in the passage. Surprisingly the net impact of labor cost in the 1986-91 window is negative (i.e. it has accelerated the process of disposal), 
and fairly sizeable: up to - 3.3 p.p. and over in the North and -2.8 p.p. in the South. The net impact in the 1992-97 window is also negative, but smaller (in absolute terms), with the interesting exception of the manufacturing sector of the South where it approaches -5 p.p among workers aged 25-30.

\section{Self-selection behind the door?}

A problem of self-selection could be raised in connection with our measurement of "disposable" workforce. The individuals whom we consider "disposed" workers once they leave the panel and are no longer observable could, in principle, be entering the business world (excluding self employment, which we do observe and account for), the public sector and/ or the professions, on a path of upward mobility. In this paragraph I intend to show that, while the problem exists, it is negligible and will leave results unchanged.

The first and stronger argument derives from par. 3 where I explain that almost all the young people who move into the public sector are observed in the WHIP database, the only exceptions being the military service and the police corps. I also explain that the number of those moving in the professions below 30 years of age is negligible.

The second consideration is that the quickly "disposed" individuals have had very short initial employment spells and are in the lowest percentiles of the wage distribution. This strongly suggest that early disposal has very negative connotations. Which is not sufficient to exclude self-selection, but is another signal that points in this direction.

The third and final argument integrates the last one. I explore the post-entry wages 5 years after the first job spell of individuals who have not been "disposed" in the first five years of career: post-entry wages appear to be strongly negatively influenced by the length of the initial spell. Additional controls are necessary to account for the impact that job-to-job mobility may have on wages. Not only do I distinguish between stayers (on their first job) and movers, but, for the latter, I also take into account the firm size of origin and destination of the last change (there could be more than one). This multiplies the number of original cells by a factor of 9 (3 x 3 firm sizes), but, as done before, we retain only those that are left with at least 3 individuals (2922). Deflated average cell wages are regressed against the variables that define the cells, including those reflecting mobility. Results are displayed in Appendix 1. A problem of self-selection might arise, in that the individuals included in this sub-sample are the "lucky" ones who have not been disposed in the first 5 years of career. This occurrence, however, would strengthen our conclusion as the significance of the initial job spell on post-entry wages could be hidden by the selection. It is not: a good start at entry (employment spells $>12$ months) is very significant and yield a premium of $48 \mathrm{EU} / \mathrm{month}$ over the shorter 
spells (the $3-12$ month-dummy is below significance, the benchmark being provided by the <less than 3 months $>$ spell $)^{20}$. The premium of a good start may, at first sight, appear too small compared to the one associated with a bad start $(<3$ months). This is not the case: in fact, we are imposing a strong restriction on the bad starts that must last at least 5 years: thus, a large number of "bad starts" get disposed before ever reaching that moment. Altogether, I feel therefore confident that self-selection is a very unlikely event.

\section{Conclusions}

The overall picture is now sufficiently clear: workforce disposal is evident and quite dramatic. The order of magnitude is consistent with the official LFS youth unemployment rate increased by a reasonable estimate of the number of workers who end up in irregular, undetectable activities. Regression analysis catches the short and medium run impact of several factors: age, initial entry conditions (the length of the first employment spell), business cycle, labor cost. The net impact of labor cost on 5-year survival is negative (i.e. it reduces survival) and relatively high in manufacturing, somewhat less in the service industries. It is more negative in the expansionary 1986-91 window, than in the recessionary 1992-97 time period. Unfortunately a complete econometric explanation of the by now 25-years long - process of workforce disposal is not at hand, for lack of data that cover the early stages of the process. Which was undoubtedly supported by a sequence of labor market reforms initiated in the mid Eighties, aimed at enhancing youth employability with the introduction of highly flexible and often subsidized working contracts. To a large extent, as argued before, the reforms sanctioned a process which was already under way.

A preliminary address to the long run perspective must rely on crosscountry comparisons of a few significant macro indicators (tab. 9). Italy and Spain are the only two European countries where employment growth 2000-08 exceeds GNP growth (at constant prices). Not only does labor productivity turn downwards (a direct consequence of the latter), but so does multi-factor productivity since 1995. This finding strongly supports the idea that the wide utilization of temporary

\footnotetext{
${ }^{20}$ Some of the other results are not surprising: age is influential; so is the geographical area (North outperforms South) and the activity branch (manufacturing looses to the services). The mobility pattern yields an interesting and highly statistically significant ranking: <big-big> is the benchmark and tops the list, followed by: <med-big> - 107, <stayers> - 111, <small-big > -137, <big-med > - 189, <med-med > - 239, <small-med > - 251, <big-small > - 258, $<$ med-small $>$ - 290, <small-small $>-319$.
} 
contracts for the vast majority of new hires ${ }^{21}$, and the ensuing process of workforce disposal (and waste of human capital) may have been the driving force behind these developments.

Additional evidence of Italy's weak position vis-à-vis the rest of its direct EU competitors is signaled by the pattern of real wages: stagnant since the early Nineties, while in the rest of Europe they were increasing by $10 \%$ in the market sectors and by $20 \%$ and over in manufacturing (fig. 9).

Tab.9: OECD 2000-2008 growth rates and multi-factor productivity

\begin{tabular}{|c|c|c|c|c|c|c|}
\hline & Employment & $\begin{array}{l}\text { GNP } \\
\text { constant prices }\end{array}$ & Labor productivity & $\begin{array}{l}\text { 1985-95 } \\
\text { MFP }\end{array}$ & $\begin{array}{l}\text { 1995-07 } \\
\text { MFP }\end{array}$ & $\begin{array}{l}\text { 2001-07 } \\
\text { MFP }\end{array}$ \\
\hline $\mathrm{Au}$ & 8,2 & 23,4 & 15,1 & & & \\
\hline $\mathrm{Be}$ & 6,7 & 16,0 & 9,3 & & & \\
\hline $\mathrm{Dk}$ & 3,9 & 10,4 & 6,5 & 1,5 & & 0,6 \\
\hline $\mathrm{Fl}$ & 8,4 & 25,0 & 16,6 & 1,3 & 0,3 & 1,6 \\
\hline Fr & 5,8 & 14,1 & 8,3 & 1,7 & 2,1 & 1,0 \\
\hline $\mathrm{Ge}$ & 6,0 & 9,7 & 3,7 & 1,4 & 1,1 & 0,6 \\
\hline $\mathrm{Gr}$ & 11,8 & 35,8 & 24,0 & & 1,0 & \\
\hline Ire & 26,1 & 43,4 & 17,3 & 3,3 & 3,5 & 2,5 \\
\hline It & 10,3 & 7,3 & -3 & 1,3 & 0,1 & $-0,7$ \\
\hline $\mathrm{Nl}$ & 7,7 & 16,5 & 8,8 & 1,0 & 0,8 & 0,7 \\
\hline Por & 3,1 & 7,9 & 4,8 & & 1,2 & 0,3 \\
\hline $\mathrm{Sp}$ & 29,9 & 28,0 & -1.9 & & 0,1 & $-0,1$ \\
\hline Swe & 10,4 & 19,8 & 9.4 & 0,5 & 1,8 & 2,7 \\
\hline Uk & 8,5 & 20,4 & 11,9 & 1,0 & 1,2 & 1,2 \\
\hline
\end{tabular}

\footnotetext{
${ }^{21}$ As is well known Spain introduced a major reform in 1996 that allowed almost all new hires to be on a temporary basis. A few years later, more restrictive rules were introduced in the legislation; nevertheless, the share of temporary workers in Spain is still much higher than anywhere else in Europe.
} 
Real wages in Italy and Eurnean Union

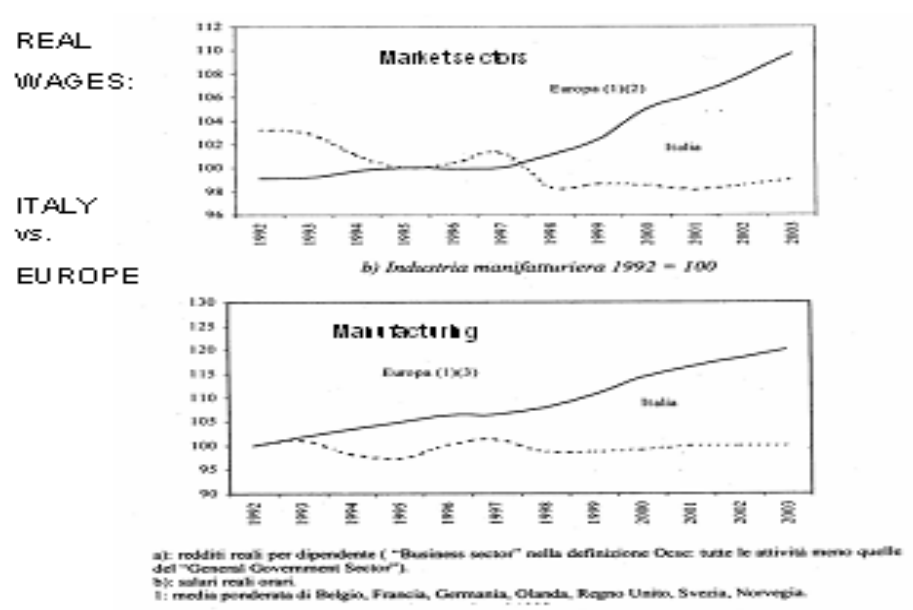

Fig. 9 


\section{APPENDIX 1}

Weighted OLS regression on real wages 5 years after first job entry

\begin{tabular}{|c|c|}
\hline & Coeff. \\
\hline Age $22-25$ & $43 * *$ \\
\hline Age 25-30 & $114 * * *$ \\
\hline North & $165 * * *$ \\
\hline Manufacturing & $-109 * * *$ \\
\hline $\begin{array}{l}\text { First spell } \\
3-12 \text { months }\end{array}$ & 15 \\
\hline $\begin{array}{l}\text { First spell } \\
12+\text { months }\end{array}$ & $48 * *$ \\
\hline $\begin{array}{l}\text { Year-of-entry } \\
\text { dummies }\end{array}$ & Yes*** \\
\hline Stayer & $-111 * * *$ \\
\hline Big-med & $-189 * * *$ \\
\hline Big-small & $-258 * * *$ \\
\hline Med-big & $-107 * *$ \\
\hline Med-med & $-240 * * *$ \\
\hline Med-small & $-290 * * *$ \\
\hline Small-big & $-137 * * *$ \\
\hline Small-med & $-251 * * *$ \\
\hline Small-small & $-319 * * *$ \\
\hline No. obs. cells & 2922 \\
\hline $\mathrm{R}^{* * \text {-adj. }}$ & 0.34 \\
\hline
\end{tabular}

\section{APPENDIX 2}

\section{A nutshell model of labor demand involving permanent vs. temporary contracts}

Different models of labor demand of young people, where employers may choose between permanent non-subsidized working contracts or subsidized temporary contracts, yield similar indications: permanent contracts are preferred to temporary contracts if the fiscal opportunity cost of not using a temporary contract plus the expected firing cost is smaller than the training cost and/or loss of productivity associated with hiring a young unexperienced worker via the subsidized contract. A very simple two-period model developed in B. Contini (2006) yields the following condition:

"permanent" is preferred to "temporary" iff

$$
\mathrm{w}(1-\mathrm{t})+(1-\mathrm{gp}) \mathrm{FC}<\mathrm{f}
$$

where:

(i) subsidy (t) $\rightarrow$ thus opportunity cost of not using "temporary" $=[\mathrm{w}(1-\mathrm{t})]$;

(ii) business conditions $[\mathrm{g}=$ probability of high aggregate demand)

(iii) worker quality ( $\mathrm{p}=$ probability of finding a good match). 
A value of (1-gp close to 1 is the probability of low demand \& bad worker quality, which leads to a layoff;

(v) training cost $\mathrm{f}$ (= opportunity loss incurred if "temporary" are hired)

The following are to be expected:

- the subsidized temporary contracts will be preferred when the wage subsidy is sufficiently high;

- the temporary contract is preferred in positions that require low skills, i.e. where the training cost of the unskilled or their foregone productivity is low;

- the advantage of hiring via permanent contracts is higher, the higher the "quality" of the candidate recruits;

- large firms will have a relative preference for temporary workers, as firing costs are higher than in small firms ${ }^{22}$.

In Italy, since the mid Nineties, the conditions favouring the wide utilization of temporary and disposable contracts were all in place (in addition, aggregate demand never fully recovered after the recession of 1992-94). As a consequence many young people - presumably those with a short experience and modest skills - were laid off at termination of the temporary contracts. Nor was there sufficient advantage for different employers to hire the ones who were laid off, as their previous experience (at most two years) would seldom be considered valuable, a minimal amount of additional training necessary, and the benefits granted by the existing provisions to new temporary hires higher than any other solution.

\footnotetext{
${ }^{22}$ Three of the four above expected results were found to hold in B. Contini (2005). No evidence was available on the one related to workers' "quality", for lack of appropriate indicators of quality.
} 


\section{Bibliography}

E. Battistin and E. Rettore, "Ineligibles and eligible non-participants as a double comparison group in regression-discontinuity designs", Journal of Econometrics (2008), n. 142.

F. Berton, M. Richiardi, S. Sacchi (2008), Flex-insecurity:perchè in Italia la flessibilità diventa precarietà, Il Mulino (2009)

O. Blanchard, "European unemployment", Economic Policy, n. 45 (2006)

B. Contini, C. Malpede and E. Rettore, "Measuring the employment impact of Italy's cflprogram: pre-historical problem, new results", WP LABOR (2005).

B. Contini and A. Poggi, "Employability of young Italian males after a jobless period 1989-98", WP LABOR (2008)

B. Contini and U. Trivellato (eds.), Eppur si muove: mobilità e dinamiche del mercato del lavoro, Il Mulino (2005).

G. Giannelli, U. Jaenichen and C. Villosio, "Have labour market reforms at the turn of the millennium changed job durations of the new entrants?", W.P. LABOR (2009).

Stewart, Mark B \& Swaffield, Joanna K, 1999, "Low Pay Dynamics and Transition Probabilities," Economica, vol. 66 (261), pages 23-42, February. 